\title{
Del protagonismo al ocaso. Las dirigencias sindicales comunistas de Córdoba ante la irrupción del peronismo (1936-1948)*
}

\author{
From the prominence to the decline. The communist union leadership of \\ Córdoba before the Peronist irruption (1936-1948)
}

Jessica Blanco $^{* *}$

\begin{abstract}
Resumen
En este trabajo se reconstruirá la acción del sindicalismo comunista en las décadas de 1930 y 1940 en la ciudad de Córdoba (Argentina) y se demostrarán las resistencias políticas y sindicales que el gobierno de 1943-46 y el peronismo generaron en sus dirigentes. A diferencia de lo que sostiene la historiografía sobre el tema, nuestra hipótesis señala que el peronismo no se encontró con un vacío organizativo entre los trabajadores, sino que varios sindicatos de trayectoria estaban organizados por los comunistas y los socialistas. Por otra parte, se subraya la autonomía que dirigentes gremiales comunistas cordobeses defendieron cuando las autoridades partidarias nacionales quisieron, luego del XI Congreso Nacional del Partido Comunista de agosto de 1946, conciliar con el sindicalismo peronista.
\end{abstract}

Palabras clave: comunismo, peronismo, sindicatos, Córdoba

\begin{abstract}
This work is going to rebuild the action of the communist union between the 1930 and 1940 decades in the City of Córdoba (Argentina) and it's going to demonstrate the political and union resistances that the 1943-46 government and the Peronism caused on its leaders. Unlike what historiography holds about this topic, our hypothesis points that the Peronism didn't found an organizational empty between the workers, but many unions of trajectory that were organized by communists and socialists. On the other hand, it is stressed the autonomy that the communist union leaders from Córdoba defended when the national party authorities wanted to reconcile with the Peronist union, after the XI National Communist Party Congress.
\end{abstract}

Key words: communism- Peronism- unions- Córdoba

\footnotetext{
*Este trabajo constituye una versión revisada de una ponencia de título similar presentada en IV Congreso Internacional de Ciencias, Tecnologías y Culturas, Santiago De Chile, 9 a 12 de octubre de 2015.

**Argentina. Doctora en Historia, Centro de Investigaciones María Saleme de Burnichón de la Universidad Nacional de Córdoba, Concejo Nacional de Investigaciones Científicas y Técnicas, Escuela de Historia de la Universidad Nacional de Córdoba (Córdoba, Argentina).jessieblanco@yahoo.com.ar
} 


\section{Introducción}

Uno de los tópicos centrales de los estudios académicos sobre los orígenes y la constitución del fenómeno peronista refirió a los apoyos sociales en los que se sustentó. Luego del golpe de Estado que destituyó a Perón en 1955, y en pleno clima antiperonista, el sociólogo Gino Germani centró su mirada sobre la supuesta falta de integración de los nuevos trabajadores industriales del gran Buenos Aires, los migrantes internos recientes pertenecientes a una Argentina rural y tradicional acostumbrados a modalidades políticas caudillistas, quienes habrían sido permeables al liderazgo carismático de Perón. Por el contrario, en las décadas siguientes Miguel Murmis y Juan Carlos Portantiero, Louise Doyon, Hugo del Campo y Juan Carlos Torre, resaltaron el rol de los dirigentes de destacada trayectoria sindical de Capital Federal y provincia de Buenos Aires -desde su perspectiva actores indispensables en la conformación del peronismo- a los que adujeron una tradición reformista que posibilitó una alianza entre la clase obrera y la elite política. ${ }^{1}$

Como bien han señalado César Tcach y Darío Macor, ambos tipos de explicaciones -que los autores denominaron ortodoxas y heterodoxas, respectivamente- se centraron en Buenos Aires y abordaron el surgimiento del peronismo como el reverso del proceso de industrialización de la década de 1930. Tcach y Macor postularon que en provincias con limitada industrialización, la inexistencia o debilidad de un proletariado urbano, determinó el predominio de otros actores en la constitución de los peronismos del interior del país. ${ }^{2}$ Sin embargo, esta propuesta explicativa, autodenominada extra-céntrica, no escapaba del razonamiento ceñido a los parámetros de los estudios centrados en Buenos Aires: se partía del supuesto -no comprobado- de la debilidad de una clase obrera (vieja o nueva) del interior, derivada de un universo económico y social ajeno a las transformaciones industriales. Así, actores políticos y sociales conservadores tendrían un protagonismo fundamental en la emergencia y trayectoria del partido peronista, en detrimento de las organizaciones obreras, que en algunos casos provinciales ni siquiera fueron estudiadas. Como un círculo vicioso, el desconocimiento generalizado en los ámbitos provinciales del accionar sindical por lo menos desde la década de 1930 se vio avalado por la interpretación extracéntrica, al tiempo que esta ausencia contribuyó a la consolidación doctrinaria de la misma en la historiografía política del primer peronismo.

\footnotetext{
${ }^{1}$ Gino Germani, Estructura social de la Argentina, Buenos Aires, Ediciones Solar, 1987 [1955]; Política y sociedad en una época de transición, Buenos Aires, Paidós, 1962; Miguel Murmis y Juan Carlos Portantiero, Estudios sobre los orígenes del peronismo, Buenos Aires, Siglo XXI, 2004[1971]; Louise Doyon, Perón y los trabajadores. Los orígenes del sindicalismo peronista 1943-1955, Buenos Aires, Siglo XXI, 2006[1978]; Hugo del Campo, Sindicalismo y peronismo. Los comienzos de un vínculo perdurable, Buenos Aires, Clacso, 1983; Juan Carlos Torre, La vieja guardia sindical y Perón. Sobre los orígenes del peronismo, Buenos Aires, Sudamericana, 1990.

2 César Tcach, Sabattinismo y peronismo. Partidos políticos en Córdoba 1943-1955, Buenos Aires, Sudamericana, 1991, 82; Darío Macor y César Tcach (eds.), La invención del peronismo en el interior del país, Santa Fe, Universidad Nacional del Litoral, 2003, 21.
} 
Respecto de la historiografía local, en los trabajos de Tcach las referencias al movimiento sindical previo y/u opositor al peronismo son escasas, ${ }^{3}$ vacíos que los estudios de Roberto Ferrero, Inés Achával Becú y quien escribe han contribuido a llenar. Asimismo, la investigación de Mariana Mastrángelo sobre el movimiento obrero de la provincia Córdoba desde fines del siglo XIX hasta mediados de la década de 1930 vino a demostrar la influencia del sindicalismo comunista durante los años ' $30 .{ }^{4}$

A nivel regional, la gravitación comunista en el movimiento obrero santafesino y tucumano durante la década de 1930 hasta el golpe militar de 1943, ha sido estudiada por Oscar Videla y Paulo Menotti; y María Fernández de Ullivarri y Esteban Piliponsky, respectivamente. Este último también aborda el periodo militar de 1943-1946, y afirma que Perón habría apelado al diálogo, la negociación y la cooptación de la dirigencia sindical. Paralelamente, y a partir de la exclusión del gremialismo disidente -que era mayoritario-, el gobierno habría promovido el proceso de sindicalización, sobre todo al organizar, o reestructurar, los gremios azucareros. ${ }^{5}$ De todas maneras, ninguno de los historiadores mencionados traspasa la barrera imaginaria del ' 46 en lo que respecta al derrotero comunista a nivel sindical y en los lugares de trabajo.

En este sentido, el objetivo general del artículo es contribuir al conocimiento del movimiento obrero organizado en espacios por fuera del área metropolitana, más específicamente la ciudad de Córdoba. Se hará hincapié en la trayectoria y marcas dejadas en el mismo por la prédica y accionar comunistas y su posicionamiento ante la

\footnotetext{
${ }^{3}$ Tcach, op. cit., 91, 93 y 172; César Tcach, "Ni cruces ni puños cerrados: la construcción de la hegemonía peronista en el movimiento obrero cordobés", Darío Macor y César Tcach (eds.), La invención del peronismo en el interior del país II, Santa Fe, Universidad Nacional del Litoral, 2013, 51-55. En este artículo el autor aborda la represión de los gobiernos peronistas cordobeses a la izquierda obrera; empero, elude cualquier revisión del extracentrismo.

${ }^{4}$ Roberto Ferrero, Del mutualismo al Cordobazo. Breve historia del movimiento obrero en Córdoba, Córdoba, Ediciones del Cepen, 2009; Inés Achával Becú, Las culturas políticas y el origen del peronismo en Córdoba (1943-1947), Tesis de Licenciatura en Historia, Córdoba, Universidad Nacional de Córdoba, 2010, inédito; "Repensando el 'Peronismo periférico': el origen del Peronismo en Córdoba 1943-1946", ponencia presentada en el Segundo Congreso de Estudios sobre el Peronismo 1943-1976, Caseros, UNTREF, 4 al 6 de noviembre de 2010; Jessica Blanco, Mundo sindical, esfera política y catolicismo en Córdoba, 1940-1955. La Juventud Obrera Católica durante el peronismo, Tesis doctoral en Historia, Córdoba, Universidad Nacional de Córdoba, 2012, inédito, capítulos 1 a 4; Mariana Mastrángelo, Rojos en la Córdoba obrera 1930-1943, Buenos Aires, Imago Mundi, 2011.

${ }^{5}$ Oscar Videla y Paulo Menotti, "Una experiencia de la militancia comunista en los orígenes del peronismo. El Sindicato de Obreros de la Industria Metalúrgica (SOIM) de Rosario, A contracorriente, 11:2, Carolina del Norte, invierno 2014, 114 -144; Menotti, Paulo, "Relaciones entre el estado santafesino, el movimiento obrero y los comunistas antes del surgimiento del peronismo (1928-1943)", ponencia presentada en XIII Jornadas Interescuelas/Departamentos de Historia, Universidad Nacional de Catamarca, Facultad de Humanidades, 10 al 13 de agosto de 2011; María Fernández de Ullivarri, Trabajadores, sindicatos y política en Tucumán. 19301943, Tesis de Doctorado en Historia, Buenos Aires, Universidad de Buenos Aires, 2010, inédita; Esteban Piliponsky, "¿Sindicatos fuertes con poder de negociación débil? Análisis del sindicalismo tucumano previo al surgimiento del peronismo", A contracorriente, 10:1, Carolina del Norte, 2012, 310-333; "De las calles a las urnas. Movimiento obrero, izquierdas y laboristas en Tucumán en la campaña electoral de 1946", Coordenadas. Revista de Historia Local y Regional, 1:2, Centro de Investigaciones Históricas de la Universidad Nacional de Río Cuarto, Río Cuarto, julio-diciembre de 2014, 118-145, disponible en http://ppct.caicyt.gov.ar/index.php/coordenadas/article/view/5241
} 
conformación y el gobierno del primer peronismo mediterráneo. Así, como objetivo específico el trabajo se propone iluminar aristas de la relación entre el sindicalismo comunista y el primer peronismo que, en los estudios historiográficos a nivel nacional han sido a priori y desde distintas perspectivas anuladas. Por un lado, por los estudiosos de los vínculos entre el movimiento obrero y Perón, al proclamarnos la temprana derrota del sindicalismo comunista ante un avasallante peronismo y mostrarnos desde 1946 un panorama uniforme de progresiva e irremediable peronización sindical. ${ }^{6}$ Por otro, por los trabajos sobre el comunismo argentino durante el primer peronismo, que centran sus análisis en el partido después de la derrota electoral de 1946 y en las disensiones internas del Partido Comunista (PC) hasta 1955. Estos llegan a la misma conclusión que los primeros, al tomar las directivas del XI Congreso Nacional del PC de agosto de 1946 como el inicio de la inexorable integración de los militantes comunistas en los sindicatos peronistas y en la CGT. ${ }^{7}$

El abordaje analítico se ubica en una historia social de lo político que enfatiza las prácticas de los actores, con una reconstrucción en el ámbito local que busca enriquecer, desde la perspectiva de las dirigencias sindicales, lo que se conoce de las relaciones entre el comunismo y el primer peronismo.

Como hipótesis se sostiene la gravitación durante las décadas de 1930 y parte de la de 1940 en Córdoba de las tendencias izquierdistas en sindicatos de trayectoria, con dirigentes obreros de extracción comunista que se opusieron y resistieron a la promoción de sindicatos paralelos y a la reestructuración de sindicatos preexistentes que realizó el peronismo. Por otra parte, se subraya la autonomía que dirigentes gremiales comunistas cordobeses defendieron cuando las autoridades partidarias nacionales quisieron, luego del XI Congreso Nacional del Partido Comunista de agosto de 1946, conciliar con el

\footnotetext{
${ }^{6}$ Doyon, op. cit., 270; Del Campo, op. cit., 187.

${ }^{7}$ Acerca de la postura partidaria del PC sobre el peronismo consúltese Alexia Massholder, "La relación entre comunistas y peronistas: algunas notas desde la historia", Cuadernos Marxistas, 5, Buenos Aires, noviembre de 2012; Aníbal Jáuregui, "El peronismo en los debates del Partido Comunista Argentino: 1945- 1953”, A contracorriente, 9: 3, Carolina del Norte, primavera 2012; Andrés Gurbanov y Sebastián Rodríguez, "La compleja relación entre el Partido Comunista Argentino y el peronismo: (1943-1955)", ponencia presentada en Primer Congreso de Estudios sobre el Peronismo, Mar del Plata, UNMdP, noviembre de 2008, disponible en http://redesperonismo.com.ar/archivos/CD1/PP/gurbanov.pdf. Una lectura de los lineamientos programáticos del partido más atenta a las prácticas en Silvana Staltari, "El Partido Comunista frente al peronismo: estrategia y tácticas políticas, 1945-1955”, Archivos de historia del movimiento obrero y la izquierda, 5, Buenos Aires, septiembre de 2014, 11-30. Por último, Marcos Shiavi se ha detenido en la trayectoria de dos fuertes sindicatos comunistas, el metalúrgico y el textil, hasta la "irremediable" incorporación al peronismo desde julio de 1946. Marcos Schiavi, "Los sindicatos comunistas entre el 17 de octubre y su disolución. El caso textil y metalúrgico”, ponencia presentada en las IX Jornadas de Sociología. Capitalismo del siglo XXI, crisis y reconfiguraciones. Luces y sombras en América Latina, Buenos Aires, Universidad de Buenos Aires, CD-ROM, 2011, disponible en http://historiapolitica.com/datos/biblioteca/pcmovo_schiavi.pdf; El poder sindical en la Argentina peronista (1946-1955), Buenos Aires, Imago Mundi, 2013.

Un recorrido historiográfico sobre la relación entre comunismo y clase obrera entre las décadas de 1910 y 1940 en Argentina en Hernán Camarero, "Antiguas controversias, nuevos enfoques: Clase obrera, sindicalismo y comunismo en la Argentina durante la primera mitad del siglo XX: Un estado de la cuestión," PolHis, 6: 11, primer semestre de 2013, 129-146, disponible en http://historiapolitica.com/datos/boletin/PolHis11.pdf
} 
sindicalismo peronista. Lo anterior brinda indicios de grados de autonomía al interior del PC que llevan a relativizar la mítica verticalidad atribuida a este partido.

En una primera instancia, reconstruyo el panorama sindical cordobés desde mediados de la década de 1930, momento en que el gobierno provincial da muestras de mayor apertura a las temáticas laborales y las organizaciones obreras aumentan, hasta el golpe de Estado de 1943, respecto del grado de sindicalización; las tendencias ideológicas predominantes en los distintos sectores productivos; los intentos de unificación en centrales obreras; y la agenda de preocupaciones que plantearon las dirigencias gremiales de acuerdo al contexto internacional y nacional.

Luego me centro en las medidas represivas llevadas a cabo en el ámbito sindical por los gobiernos nacionales anteriores y posteriores al golpe de 1943, que afectaron mayoritariamente a los comunistas, quienes primero fueron proscriptos y luego sufrieron la competencia de entidades gremiales pro gobierno. Por último, analizo la persistente oposición peronista de sindicalistas comunistas emblemáticos que, a pesar de las directivas nacionales del partido de agosto 1946 de disolver sus agrupaciones e integrarse en los sindicatos oficialistas, mantuvieron su autonomía hasta 1948.

Las fuentes utilizadas refieren a documentación municipal, provincial y nacional que da cuenta de las solicitudes, composición y posicionamiento ideológico de sindicatos gravitantes en los sectores de la producción y servicios. Asimismo, esta información fue complementada con la brindada por los diarios locales de la época, sobre todo respecto de los conflictos laborales, los ensayos de unificación obrera y las relaciones con otros actores políticos.

\section{El movimiento obrero sindicalizado de la ciudad de Córdoba hasta 1943}

La incorporación de la provincia de Córdoba al modelo agroexportador argentino se fortaleció con la incorporación agrícola de las tierras del este y sur. De todas maneras, y como consecuencia de la crisis económica internacional desatada en 1929, esta provincia, como ocurría a nivel nacional, se vio obligada a profundizar un proceso sustitutivo espontáneo, iniciado durante la Primera Guerra Mundial, para responder a las necesidades de consumo interno. No obstante, entre 1935 y 1945 el perfil productivo de su capital no registró modificaciones sustanciales respecto de una mayor heterogeneidad. En 1946 las estadísticas daban cuenta de la escasa gravitación de la industria cordobesa a nivel nacional y de su falta de diversificación: el sector alimentario continuaba concentrando la producción (mataderos, cervecerías, molinos harineros). Ese año dicho rubro, perteneciente a la industria liviana tradicional, ocupaba el 47,9\% de los empleos industriales de la ciudad, en tanto un $9 \%$ correspondía a lo que podrían llamarse industrias intermedias, primordialmente la producción de cemento. Si bien un $43 \%$ de las ocupaciones industriales se relacionaban con áreas "no tradicionales", casi todas se hallaban concentradas en solo dos empresas: la Fábrica Militar de Aviones y los talleres del Ferrocarril, establecimientos 
dedicados al mantenimiento y la reparación, pero no a la producción de maquinarias. ${ }^{8}$ La situación comenzó a cambiar en el transcurso de los cincuenta, dado que en 1954 el censo mostraba un perfil industrial más dinámico. Podemos afirmar que hasta los primeros años de la década de 1950 Córdoba careció de un grado significativo de desarrollo industrial vinculado a los sectores más dinámicos de la economía.

Cabría preguntarse entonces acerca de las particularidades y gravitación social del conjunto obrero en Córdoba, y dentro de este del sector sindicalizado.

Se carece de estadísticas respecto del grado de sindicalización en la ciudad de Córdoba para la década de 1930, pero existen indicios de que hasta fines de 1943 los trabajadores mostraron desinterés por adherirse a las estructuras sindicales. La falta de apoyo de las bases obreras a proyectos presentados por los dirigentes gremiales y la indiferencia ante el insistente llamado para asistir a las asambleas organizativas eran denunciadas por los socialistas y por sindicatos con cierta trayectoria, como los sastres y los conductores de ómnibus. ${ }^{9}$ Probablemente una de las razones de la inasistencia se relacione con el temor a las represalias patronales, ya que el funcionamiento de los sindicatos no estaba reglamentado. Sobre la base de datos extraídos del Diario de Sesiones de la Cámara de Diputados provincial, María José Ortiz Bergia afirma que hacia 1936 había 195 sindicatos en la provincia, 35 de ellos en la ciudad de Córdoba. ${ }^{10}$ Un lustro después, según la Memoria de 1941 del Departamento Provincial del Trabajo (DPT), en la provincia los "sindicatos, asociaciones obreras y centros de empleados de comercio" habían ascendido meteóricamente a 424, es decir que se verificaba un aumento de más del 100\%. Entre ellos se destacan los siguientes: 70 eran sindicatos de oficios varios, 49 agrupaban a conductores de carros y camiones, 47 a estibadores y 5 a obreros rurales, lo que muestra la importancia de la economía rural con más del $40 \%$ de las organizaciones, en las que anarquistas y comunistas tenían fuerte presencia. Dentro del sector terciario y de servicios pueden mencionarse 15 sindicatos de comercio, 33 ferroviarios, 3 gráficos, 17 del transporte automotriz, 13 de mozos y cocineros, 7 de obreros del Estado y 6 de personal doméstico. Entre los obreros de la producción sobresale la rama alimentaria, con 24 gremios (14 panaderos, 4 molineros, 3 del dulce y 3 fideeros) y la de la construcción, con 43 (25 de obreros de la construcción, 8 ladrilleros, 5 mosaiquistas, 2 caleros, 1 yesero, 1 del portland y 1 de pintores). Por último, los metalúrgicos se hallaban nucleados en 5 sindicatos. ${ }^{11}$

\footnotetext{
${ }^{8}$ Alicia Malatesta, "La actividad industrial en Córdoba (1930-1955)", Beatriz Moreyra y Beatriz Solveira, Estado, economía y sociedad en Córdoba, 1880-1950 I, Córdoba, CEH, 1997, 53; James Brennan, El Cordobazo. Las guerras obreras en Córdoba, 1955-1976, Buenos Aires, Sudamericana, 1994, 50 y 55.

${ }^{9}$ Testimonio del ferroviario Luis Monzalvo en Del Campo, op. cit., 172; Ofelia Pianetto, "Sindicatos y política en Córdoba (1930-1943)", César Tcach (coord.), Córdoba bicentenaria. Claves de su historia contemporánea, Córdoba, CEA-UNC, 2010, 222 y 229; Daniel Darío Amuchástegui, Gobierno y oposición ante la cuestión social en Córdoba, 1932-1936, Tesis de Licenciatura en Historia, Córdoba, 1986, inédito, 13 y 52; referencias al caso riocuartense en Mastrángelo, op. cit., 242-243.

${ }^{10}$ María José Ortiz Bergia, La construcción del Estado Social en Córdoba entre 1930-1943: Actores y concepciones en un período de transición, Tesis de Licenciatura en Historia, Córdoba, 2007, inédito, 59.

${ }^{11}$ Memoria de 1941 del Departamento Provincial del Trabajo, en Archivo de Gobierno de la Provincia de Córdoba, Serie Gobierno, tomo 40, año 1932-1942, 31 de diciembre de 1941, f. 494. Cabe aclarar que este informe presenta la representación gráfica del peso de cada área gremial. Si seguimos el cuadro la suma obtenida es 424, pero el escrito indica que se trata de 365. Aquí se siguió la primera cifra. Ofelia Pianetto, op.
}

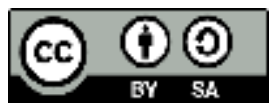


Ahora bien ¿Cómo puede explicarse semejante crecimiento numérico en tan pocos años, en comparación con los guarismos nacionales? ${ }^{12}$ El lustro en cuestión coincide prácticamente con la gobernación radical de Amadeo Sabattini (1936-1940), que se caracterizó por un mayor intervencionismo en los asuntos laborales y la efectivización de leyes favorables a los trabajadores. En contraposición con las restricciones sufridas en el resto del país, el ejercicio de las libertades públicas por parte de las izquierdas favoreció la presencia y el desarrollo de los partidos comunista y socialista en el movimiento obrero de Córdoba. ${ }^{13}$ Ciertamente, esta política de la Unión Cívica Radical (UCR) provincial pudo beneficiar la multiplicación de organizaciones de trabajadores, sin embargo las cifras oficiales del DPT parecen sobredimensionar el peso de las entidades obreras, al no distinguir sindicatos de agrupaciones que decían representar a los obreros, como el "Centro de Obreras Femeninas". Con todo, los números nos están demostrando que durante este gobierno hubo mayor libertad e incentivo estatal para con la organización de los trabajadores.

El censo nacional de 1947 nos muestra una distribución demográfica similar entre el área urbana $(52 \%)$ y rural $(48 \%) .{ }^{14}$ No obstante, de un porcentaje relevante de población rural (sin embargo, no tan elevado respecto de la media nacional) y de una incipiente y tímida industrialización -en comparación con Buenos Aires-, no puede inferirse la inexistencia y/o irrelevancia de los trabajadores asalariados (incluidos los obreros industriales) entre la población económicamente activa, y de organizaciones sindicales en defensa de sus derechos. En otras palabras, existían sindicatos de trabajadores empleados en el sector primario y de servicios, y, dada la estructura económica de la época, en menor medida en las manufacturas.

A nivel ideológico, podemos afirmar que desde mediados de la década de 1930 en términos generales los socialistas predominaron en los gremios del sector terciario y de servicios (empleados de comercio, ferroviarios, tranviarios), mientras la prédica comunista fue preponderante entre los obreros gráficos y de la producción (construcción, metalurgia y alimentación) que cubrían el mayor porcentaje de la actividad económica. La presencia anarquista en la ciudad se encontraba en los gremios de cocineros y pasteleros, panaderos y oficios varios, los cuales tenían vinculaciones con la Federación Obrera Regional Argentina (FORA) V Congreso. ${ }^{15}$

En 1936, el cambio de la estrategia comunista a favor de la formación de los frentes populares permitió el acercamiento entre los sindicatos comunistas y socialistas, que resultó en la fundación de la central Federación Obrera Provincial (FOP). Su comisión directiva de 1938 refleja el equilibrio de fuerzas entre comunistas y socialistas producto de la política

cit., 237. Cf. María José Ortiz Bergia, "Construcción de políticas laborales en Córdoba, 1930-1943" en Población y sociedad, 16, Tucumán, 2009, 160.

${ }^{12}$ Conforme el Censo de Asociaciones Profesionales de 1940, había 356 organizaciones gremiales registradas, de las cuales 217 pertenecían a la Confederación General del Trabajo (CGT) socialista-comunista, 31 a la Unión Sindical Argentina (USA) sindicalista, 25 a la Federación de Asociaciones Católicas de Empleadas católica y 83 a autónomos. Murmis, op. cit.

${ }^{13}$ César Tcach, "Izquierda, movimiento obrero e intervencionismo estatal durante el gobierno de Amadeo Sabattini”, ponencia presentada en las Segundas Jornadas Nacionales de Historia de Córdoba, Córdoba, CDROM, mayo de 2011.

${ }^{14} \mathrm{http}: / /$ www.cepal.org/publicaciones/xml/4/7394//cg2140_tabpaises.pdf, p. 28.

${ }^{15}$ Ferrero, op. cit, 92-93 y 97; La Voz del Interior, 25 de agosto de 1940, p. 12 y 4 de mayo de 1941, p. 22.

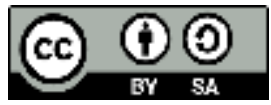


frentista, con una importante presencia de dirigentes del gremio de la construcción, liderado por los primeros. El secretario general Cruz Ramírez, el prosecretario Antonio Gómez y los vocales Carlos Pérez, Enrique Viccini (obreros de la construcción) y Carlos Céliz (gráfico) eran comunistas, lo mismo que el tesorero Roque Guillén; mientras el protesorero Julio Rodríguez (maderero) y los vocales Miguel Ávila (secretario general de los sastres), Pedro Magallanes (trabajador del calzado) y Antonio D'Elía (sastre) militaban en el socialismo. Del resto de la comisión directiva (Domingo Zaragoza -construcción-, Hernán Luna, Samuel Edwards, Fernando Vaisbein y Orfeo Moro) ${ }^{16}$ se desconoce su inclinación partidaria. Esta unidad entre socialistas y comunistas se mantuvo hasta que los últimos pretendieron alinear la central a la política soviética de neutralidad (por el pacto de no agresión entre la Unión Soviética y Alemania firmado en agosto de 1939). En consecuencia, en octubre de 1940 los socialistas fundaron una nueva entidad: la Comisión Cooperadora de la CGT. Allí estaban representados, entre otros, los dos sindicatos ferroviarios (La Fraternidad y Unión Ferroviaria -UF-), el del calzado y los empleados de comercio. ${ }^{17}$ Por su parte, los comunistas continuaron en la FOP, más allá del intento de la CGT -que integraba- de disolverla por decreto. Esta división repercutió debilitando la representación sindical, a pesar de la coincidencia en las demandas. ${ }^{18} \mathrm{El}$ acercamiento entre ambas centrales obreras locales se produjo recién un año después, cuando el ataque de Alemania a la Unión Soviética en junio de 1941 condujo nuevamente a los comunistas a sumarse al frente antifascista. Sin embargo, el golpe de junio de 1943 encontrará a los socialistas en la Comisión Cooperadora de la CGT, liderada por el ferroviario Bruno Herrera, y a los comunistas en la por ese entonces Unión Obrera Provincial (UOP). ${ }^{19}$

Detenernos en la organización de los actos del $1^{\circ}$ de mayo servirá de indicador de las alianzas y reagrupamientos mencionados. Así, por ejemplo, en 1935 la conmemoración organizada por el socialismo es respaldada por la central obrera Federación Obrera Local y los sindicatos autónomos, no así por la UOP, que seguía la política ultraizquierdista de "clase contra clase" adoptada en 1928 por el VI Congreso de la Internacional Comunista. En cambio, en 1938 encontramos juntos al Partido Socialista (PS) y al comunismo -ya nucleados en la FOP- y además a un representante de la FORA anarquista. Esta coalición se evidencia por la adhesión de sindicatos dirigidos por comunistas: la Asociación Limitada de Trabajadores de Ómnibus, caleros y mosaiquistas; anarquistas: los gastronómicos y los panaderos; y socialistas: la Unión Ferroviaria. También están presentes otros actores políticos y sociales, como el Partido Socialista Obrero (escisión de grupos troskistas del PS), la Federación Vecinal (presidida por Pascual Matassini, en ese momento vinculado al radicalismo) y el Comité de Ayuda al Pueblo Español, asociado a las campañas de solidaridad con la España republicana, representado por Gregorio Berman. En 1939 el panorama es similar, aunque en los dos años siguientes el PC y el PS realizan actos por

\footnotetext{
${ }^{16}$ El País, 20 de abril de 1938, p. 12 y 10 de abril de 1938, p. 7; Torcuato Di Tella, Perón y los sindicatos. El inicio de una relación conflictiva, Buenos Aires, Ariel, 2003, 132.

${ }^{17}$ La Voz del Interior, 20 de noviembre de 1940, p. 11.

${ }^{18}$ La Voz del Interior y El País, 9 de noviembre de 1940, p. 11 y 10 respectivamente; Ferrero, op. cit., 101; La Voz del Interior, 20 y 29 de noviembre de 1940, p. 11 y 9 respectivamente; El País, 29 de noviembre de 1940, p. 7.

${ }^{19}$ Ferrero, op. cit., 101 y 103.
} 
separado. En 1941 se organizaron cuatro eventos en recordación del $1^{\circ}$ de mayo, ya que la Juventud Radical y la CGT se sumaron a la competencia por la significación laica de la fecha. En 1942, la alianza en la lucha antifascista se manifiesta en el acto organizado por la CGT con el apoyo del PS, el PC y agrupaciones vecinales. ${ }^{20}$ Durante esos años los partidos mencionados más el radicalismo y los independientes conformaron un frente antifascista a través de tres organizaciones: la Acción Argentina (integrada principalmente por socialistas), la Agrupación Pro Unidad Democrática (de mayoría comunista) y la Confederación Democrática Argentina de Ayuda a los Pueblos Libres (comunistas, radicales e independientes), que luego del golpe de 1943 serán clausuradas, aunque incidirán en la constitución de la Unión Democrática en 1945 . $^{21}$

Los cambios de las alineaciones de los partidos políticos respecto de los países enfrentados en la Segunda Guerra Mundial también tuvieron repercusiones en el accionar gremial desde la perspectiva de los reclamos político-ideológicos. Así por ejemplo, entre octubre y noviembre de 1940 sindicatos relacionados con la producción (mosaiquistas, de la construcción, biseladores, vidrieros y anexos, Sociedad de Resistencia Panaderos y Anexos -integrantes de la Comisión Popular Pro-solución del transporte- y el sindicato de la madera), varios de ellos cercanos al comunismo, exigieron a la Municipalidad que controlara a la norteamericana Compañía de Tranvías, que competía deslealmente con el servicio de ómnibus. Acusaban a dicha empresa de llevarse el dinero a bancos extranjeros y solicitaban que las líneas de transporte automotor fueran concedidas a capitales argentinos, como un "estímulo a la industria nacional floreciente" y porque "...es la aspiración de que el transporte sea una cosa argentina y patriota para el engrandecimiento de la provincia..."22 Ahora bien, ¿podrían interpretarse estos elementos como respaldo de la tesis de Hiroshi Matsushita respecto de la progresiva conformación de una conciencia nacional en la clase obrera? ¿O acaso los comunistas -que apoyaron al radicalismo en las elecciones provinciales de 1935- habrán coincidido con el gobernador Sabattini en su prédica nacionalista? Probablemente esta solicitud pueda leerse como un ataque a los imperialismos varios -entre ellos el representado por la norteamericana Compañía de Tranvías-. En ese sentido es interesante la postura de Hernán Camarero cuando dice que el nacionalismo fue alimentado también por el PC, por ejemplo promoviendo campañas pro industria nacional, más por pragmatismo que por convicciones y dentro de su lucha antiimperialista general de los años 1939-1941. ${ }^{23}$ Sin embargo, en marzo de 1943 y bajo un contexto económico de alta desocupación la FOP pedirá, nuevamente siguiendo la estrategia de los frentes populares, no solo el restablecimiento de las relaciones diplomáticas y comerciales con

\footnotetext{
${ }^{20}$ Pianetto, op. cit., 238; La Voz del Interior, 1 de mayo de 1938, pp. 13 y 16; El País, 1 y 3 de mayo de 1939, p. 7 y 13; 1 de mayo de 1940, p. 10; 3 de mayo de 1941, p. 10; 21 de abril de 1942, p. 11 y 1 de mayo de 1942, p. 11.

${ }^{21}$ Achával Becú, Las culturas politicas..., op. cit., 128-132.

${ }^{22}$ Archivo Histórico Municipal, Documentos del Concejo Deliberante, año 1939, A-2-122, fs. 349-366. Ya en 1938 los comunistas se opusieron a la ordenanza 3552 del transporte al considerar que conducía al monopolio por parte de empresas extranjeras, a la supresión del capital interno y al encarecimiento del servicio. $L a$ Voz del Interior, 21 de enero de 1938, p. 7.

${ }^{23}$ Hiroshi Matsushita, Movimiento obrero argentino 1930-1945, Buenos Aires, Hyspamérica, 1986 [1983], 18, 199 y 228-229; Hernán Camarero, curso de posgrado "Movimiento obrero e izquierdas en Argentina, 18901945. Nuevos problemas y enfoques”, ciudad de Córdoba, 24 de junio de 2010.
} 
Rusia, sino también la mejora de las relaciones con los Estados Unidos e Inglaterra, ${ }^{24}$ pocos años atrás consideradas potencias imperialistas. Las centrales sindicales locales también se manifestaron ante la Guerra Civil Española y la Segunda Guerra Mundial: los socialistas realizaron actos en solidaridad con el pueblo español y se pronunciaron contra el "nazifascismo", mientras a nivel nacional pidieron la ruptura de relaciones con el Eje. ${ }^{25}$ Asimismo, en el Congreso de Unidad Obrera de febrero de 1943 los comunistas respaldaron la exigencia de la CGT de romper con el Eje, y solicitaron la reanudación de relaciones con Rusia y la participación popular en el movimiento de ayuda a las naciones que luchaban "contra la bestia nazi-fascista". ${ }^{26}$

Igualmente, las problemáticas políticas nacionales fueron objeto de preocupaciones públicas de las dirigencias sindicales. Las solicitudes, las motivaciones de los paros nacionales y los temarios de las manifestaciones gremiales brindan indicios acerca de la autorepresentación de los trabajadores organizados como defensores de las instituciones argentinas y de la democracia. Al respecto son ilustrativos el pedido en 1938 de dirigentes sindicales comunistas de la derogación de la ley de residencia; la solicitud del sindicato de ladrilleros del retorno del presidente Roberto Ortiz a su cargo en febrero de 1941; el paro nacional de marzo de 1943 liderado por la FOP con el objetivo de restablecer "la normalidad constitucional en el país, levantamiento del estado de sitio, libertad de prensa, de reunión, de asociación y de palabra; respeto a la voluntad popular, a la letra y al espíritu de la ley Sáenz Peña; respeto a las autonomías provinciales", o el temario de la conmemoración del $1^{\circ}$ de mayo de ese mismo año, que insistió en su reclamo por el cumplimiento de la Constitución, la unidad nacional de los partidos democráticos nucleados en la Unión Democrática, y denunció las restricciones a las libertades de un gobierno considerado fraudulento. $^{27}$

Por último y en el plano de las reivindicaciones estrictamente gremiales, entre 1938 y el golpe de junio de 1943 la agenda planteada en los congresos de las centrales obreras locales giró en torno a la crisis económica, que golpeaba fuertemente en el costo de vida de los trabajadores y se traducía en salarios cada vez más insuficientes para afrontar la vida cotidiana. Asimismo se fomentaba, como ya mencioné, la intervención estatal para atemperar la desocupación a través de la obra pública y de la actividad minera y agraria. Hasta 1939, respecto de la organización sindical la mayor preocupación estuvo centrada en la conformación de una sola central obrera, tema que volvió a ser prioritario en 1942 y 1943 , coincidente con el regreso a la estrategia unionista de los comunistas. ${ }^{28}$

\footnotetext{
${ }^{24}$ La Voz del Interior, 4 de marzo de 1943, p. 9.

${ }^{25}$ Amuchástegui, op. cit., p. 19; El País, 1 de noviembre de 1941, p. 4, La Nación, 20 de diciembre de 1942, p. 15; Matsushita, op. cit., p. 239.

${ }^{26}$ La Voz del Interior, 15 de febrero de 1943, p. 9.

${ }^{27}$ La Voz del Interior, 22 de enero de 1938, p. 5; 11 de febrero de 1941, p.10; 4 de marzo de 1943, p. 9 y 3 de mayo de 1943, pp. 11 y 15.

${ }^{28}$ Cito como ejemplo el Congreso Extraordinario de la Confederación de Trabajadores en El País, 9 y 11 de abril de 1938, pp. 7 y 3 respectivamente; 2 de abril de 1939, p. 7 y 20 de mayo de 1942, p. 10. Véanse también los reclamos económicos, laborales y sindicales del Congreso de Unidad Obrera que en febrero de 1943 reunió a 90 delegados de 77 organizaciones obreras de la ciudad de Córdoba y del interior provincial y que fue conducido por los principales sindicalistas comunistas. La Voz del Interior, 13 y 14 de febrero de 1943, p. 7 y 15 de febrero de 1943, p. 9; Ferrero, op. cit, p. 103.
} 
La combatividad de los comunistas locales atraía a los obreros expuestos a las peores condiciones laborales, como los de la construcción, la alimentación y los metalúrgicos, pero en estos años sus movimientos y estrategias políticas y sindicales dependían más de las directivas del Comintern que de factores internos. ${ }^{29}$ Así, se constata que los momentos de mayor disposición coalicionista no coinciden con modulaciones sociopolíticas locales sino con cuestiones y momentos íntimamente relacionados a la situación internacional de la Unión Soviética: 1935-1939 y 1941, periodos coincidentes con la puesta en práctica de la estrategia comunista del frente popular antifascista.

\section{Los sindicatos bajo dirección comunista ante la política represiva antes y después del golpe de 1943}

Durante los gobiernos radicales, el incremento de asociaciones obreras -entre ellas sindicatos- fue notable; probablemente haya contribuido a esta situación que la UCR se haya mostrado en el poder como un partido abierto a las demandas de los trabajadores a través de la sanción de leyes obreras y el apoyo de los conflictos gremiales; sin embargo esto no fue óbice para controlar las actividades izquierdistas en estas organizaciones. En efecto, la política obrerista de los radicales convivió durante 1942 y 1943 con el control policial impartido hacia las tendencias izquierdistas en el interior del movimiento obrero, en momentos en que socialistas y comunistas ya se habían alejado de los sabattinistas por su posición neutral ante la Segunda Guerra Mundial. ${ }^{30}$ Concretamente, el gobierno provincial de Santiago del Castillo (1940-1943) llevó a cabo investigaciones por el desarrollo de ideas fascistas y de militancia comunista (algunas vinculadas con los sindicatos), en el marco de un procedimiento nacional para la represión de actividades antiargentinas. En abril de 1942, la policía allanó la sede del PC en Córdoba, detuvo a numerosos dirigentes, comenzó a elaborar un informe sobre actividades comunistas y prohibió la realización de una conferencia regional de la Federación Obrera Nacional de la Construcción (FONC), pues quería impedir que la misma fuera utilizada "por los elementos comunistas que tienen acaparada la dirección del gremio de la construcción, para llevar a cabo en forma clandestina sus deliberaciones..."31 De acuerdo con el informe policial mencionado, solo dos de los detenidos (Isacc Blatt y Félix Aguirre) estaban vinculados con actividades gremiales. $^{32}$

\footnotetext{
${ }^{29}$ Archivo de Gobierno de la Provincia de Córdoba, Serie Gobierno, 1941, Tomo 27, pp. 207-208; Del Campo, op. cit., 61-62 y 95. Sobre el PC en la provincia de Córdoba (peso electoral, principales referentes y vinculación con la UOP) hasta los años '30 véase Hernán Camarero, A la conquista de la clase obrera. Los comunistas y el mundo del trabajo en la Argentina 1920-1935, Buenos Aires, Siglo XXI, 2007, libro que estudia los lineamientos ideológicos, discursos y prácticas comunistas en el movimiento obrero. También puede consultarse Mastrángelo, op. cit.

${ }^{30}$ Ferrero, op. cit., 96.

${ }^{31}$ Archivo de Gobierno de la Provincia de Córdoba, Serie Gobierno, 1942, Tomo 21, p. 226, 19 de mayo de 1942; 1941, Tomo 27, pp. 204-205 y 207-208 del 7 de abril de 1942; El País, 5 y 12 de abril de 1942 , p. 7 y 11 , respectivamente.

${ }^{32}$ Archivo de Gobierno de la Provincia de Córdoba, Serie Gobierno, 1941, Tomo 27, pp. 207-208.
} 
A nivel nacional, el golpe de Estado de junio de 1943 fue percibido favorablemente por la mayoría de los sectores políticos, económicos y sociales, con excepción del PC, que desde un principio denunció su carácter reaccionario. La respuesta gremial fue heterogénea: sindicatos tradicionales y sólidos como los tranviarios y los ferroviarios apoyaron al gobierno a cambio de beneficios largamente reclamados, aunque luego La Fraternidad pasó a la oposición. Los que estaban bajo conducción comunista se declararon contrarios al gobierno, que continuó proscribiendo las organizaciones de esta tendencia. Entre ellos cabe destacar a la FONC y a la Federación Obrera de la Alimentación, dos de los siete gremios obreros más poderosos del país. ${ }^{33}$

En Córdoba, la intervención federal disolvió los poderes Ejecutivo y Legislativo, mientras a nivel municipal la renuncia del intendente radical Donato Latella Frías a fines de junio marcó el comienzo de una irregularidad institucional que se prolongó hasta 1958. La actividad gremial, en correspondencia con lo que sucedía en todo el país, fue reprimida a través de la intervención de la CGT local, la clausura de todas las entidades gremiales y -por disposición del gobierno nacional- la suspensión de asambleas, reuniones públicas y comisiones directivas gremiales. La reacción de los sindicatos -principales blancos de estas medidas por considerarlos subversivos- fue la cautela, evitando cualquier proclama o pronunciamiento sobre el nuevo gobierno militar, a diferencia de lo enunciado por las dos CGT y la USA a nivel nacional. La estrategia del sindicato de la construcción local liderado por los comunistas fue la más osada y se ubicó entre el elogio aparente y la crítica, al manifestar su adhesión a los propósitos enunciados por el gobierno, sobre todo en política económica -la fijación de precios a los artículos de primera necesidad-, a la vez que sugería elecciones libres para retornar al estado institucional y el alineamiento con los aliados. A la vez, varios sindicatos como la Federación Obrera del Transporte Automotor Interprovincial, panaderos, mozos, biseladores, vidrieros, fideeros, confiteros, cocineros, obreros de la construcción y la UOP solicitaron autorización para reunirse y abrir sus locales para continuar con el funcionamiento de las bolsas de trabajo. ${ }^{34}$

A la suspensión de las actividades gremiales y la disolución de algunas de estas entidades, en julio se sumó el decreto de asociaciones profesionales, que completaba el cuadro represivo hacia las dirigencias sindicales que actuaban políticamente. ${ }^{35}$ Dichas medidas dejaron forzados vacíos de representación que fueron aprovechados por otros actores, en este caso el Círculo Católico de Obreros de Córdoba, para la reestructuración de sindicatos preexistentes o la promoción de nuevos. ${ }^{36}$

\footnotetext{
${ }^{33}$ Córdoba, 7 de septiembre de 1945, p. 2; Doyon, op. cit., 101-105 y 112; Del Campo, op. cit., 175.

${ }^{34}$ Archivo de Gobierno de la Provincia de Córdoba, Serie Gobierno, 1942, tomo 49, f. 260v.; 1943, tomo 43, fs. 541, 349-350 y 541; La Voz del Interior, 7 y 8 de julio de 1943, p. 11 y 9 respectivamente. En el caso de los panaderos, firmaron como "Sociedad de Panaderos y Ayuda Mutua", obviando el calificativo anarquista "de resistencia" y aclarando que no eran una organización subversiva.

${ }^{35}$ Entre otros, se encontraban detenidos por actividades comunistas los dirigentes sindicales Isacc Blatt y Jacobo Mazer (comercio), Carlos Céliz (gráfico), Carlos Pérez (FOP y construcción). Archivo General de la Nación, Ministerio del Interior. Comisión Ordenamiento de Archivos. Expedientes secretos, confidenciales y reservados, caja 11, expediente 503-Reservado, 13 de septiembre de 1943.

36 Sobre esta exitosa iniciativa sindical confesional consúltese Jessica Blanco, "Religión, sindicalismo y política en los años '40: una revisión sobre la participación católica en los sindicatos durante los años
} 


\section{Los sindicatos izquierdistas durante el gobierno militar: proscripción, oposición y desplazamiento}

Durante el primer año de intervención federal, la actividad obrera organizada se limitó a las reuniones asamblearias y a la presentación de solicitudes al DPT para que interviniera en discusiones salariales o firmas de pliegos de condiciones -en varios casos con resolución positiva para los trabajadores-. No obstante, la derogación en abril de 1944 de la reglamentación del decreto de julio de 1943 del Comisionado Federal de Córdoba siguiendo directivas nacionales, abrió una etapa de mayor flexibilidad sindical. ${ }^{37}$

Hacia 1944 coexistía la CGT de signo izquierdista con los sindicatos patrocinados por el Círculo Católico de Obreros, favorable al gobierno militar. La primera, estaba dirigida por el ferroviario socialista Bruno Herrera y se había apartado de las acciones oficialistas de la CGT y de la Unión Ferroviaria nacional, constituyendo un foco de resistencia a la Delegación Regional de la Secretaría de Trabajo y Previsión (DRSTyP). Esta situación produjo enfrentamientos entre la central nacional y la local que terminaron en julio de 1945 con la reorganización por parte del Secretariado Nacional de la CGT de la regional Córdoba, aunque este cambio no significó la destrucción del sindicalismo independiente.

Hacia mediados de 1944 y luego de la depuración del DPT de las antiguas autoridades y funcionarios vinculados con el nacionalismo católico, la DRSTyP comenzó una política de atracción de trabajadores a través de la vía sindical. Del mismo modo que a nivel nacional, la dependencia de Trabajo se encargó de fomentar sindicatos paralelos o en sectores aún no agremiados, pero también captó aquellos recientemente creados o rediseñados por el Círculo Católico de Obreros (algunos de ellos en pugna con los de izquierda); excepcionalmente sumó a unos pocos dirigentes de trayectoria socialista y anarquista. El resultado fue la constitución durante los primeros meses de 1945 de la central oficialista Federación Obrera de Córdoba (FOC). Por el contrario, y como veremos a continuación, los sindicatos más importantes que se mantuvieron opositores al peronismo sufrieron la competencia de organizaciones paralelas a las que se les otorgó la personería gremial correspondiente.

Cabe aclarar que los nuevos sindicatos del bienio 1944-1945 no fueron necesariamente oficialistas y/o impulsados por el Círculo o la DRSTyP. Al respecto cito el caso del sindicato de tabacaleros, que se constituyó a fines de 1945 y adhirió a la antiperonista Unión Obrera Local, aunque finalmente en 1948 se sumó a la CGT intervenida. El sindicato obrero de los mataderos de Córdoba también surgió en 1945 como

formativos del peronismo", Gardenia Vidal y Jessica Blanco (comps.), Catolicismo y política en Córdoba, siglos XIX y XX, Córdoba, Ferreyra Editor, 2010, 133-163.

37 Más allá del mantenimiento de las detenciones de los principales líderes, la actividad comunista clandestina, a veces proveniente de fuera de la provincia, continuaba a través de la distribución de propaganda. Archivo General de la Nación, Ministerio del Interior. Comisión Ordenamiento de Archivos. Expedientes secretos, confidenciales y reservados, caja 41, expediente 1001 y 1002, diciembre y noviembre de 1944, respectivamente.

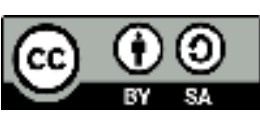


opositor al gobierno militar. Según Roberto Ferrero, la mayoría de su comisión directiva simpatizaba con el radicalismo pero cuando en 1951 uno de sus principales dirigentes, Juan Falaschetti, se convierte al peronismo, logra el pasaje de todo el sindicato. ${ }^{38}$

Entre los conflictos obreros se destacan los protagonizados en octubre de 1944 por los trabajadores de la construcción y entre diciembre de ese año y enero del siguiente por los panaderos. Los primeros apelaron como medio de protesta al abandono de los lugares de trabajo y la violencia contra las herramientas, mientras los segundos al cese de actividades nocturnas en pos de su abolición y en reclamo de aumento salarial y del cumplimiento de leyes. Ambas medidas fueron declaradas ilegales por la DRSTyP. ${ }^{39}$

En abril de 1945, luego de la progresiva liberación de los presos políticos y la conformación más orgánica de un frente político opositor, estas entidades gremiales, junto a los sindicatos de la madera, de pintores, de ladrilleros, metalúrgico, el Centro de Viajantes de Comercio, el Centro de Empleados de Comercio y la Unión de Mozos, conformaron el Comité Intersindical. Sus principales preocupaciones económicas giraban en torno a la carestía de la vida, mientras a nivel sindical defendían la independencia del movimiento obrero y de las leyes laborales; además bregaban por la libertad de los presos políticos. ${ }^{40}$

Tanto la CGT local como el Comité Intersindical desaprobaron el surgimiento de la FOC por considerarla oficialista y nacida al calor de la DRSTyP. De todas maneras, entre las centrales de izquierda las posiciones eran irreconciliables, dado que los sindicalistas comunistas reconocían la línea de conducta trazada por la Internacional que excedía la temática gremial. Coincido con Tcach en que desde sus inicios la FOC estuvo desvinculada de la Iglesia y fue planeada por el peronismo como una herramienta política para eliminar el sindicalismo independiente. ${ }^{41}$ Ahora bien, ¿la central logró ese objetivo? Su mayor aporte fue la cooptación y creación de gremios paralelos a los liderados por comunistas y socialistas, como ocurrió con peluqueros, sastres, metalúrgicos, mozos y confiteros, en este último caso a través de la atracción del antiguo anarquista Federico De Uña. Sin embargo, dichos sindicatos eran poco gravitantes numéricamente, situación que repercutió en el escaso poder de movilización de la Federación Obrera de Córdoba. En cuanto a las centrales opositoras, para doblegar a la CGT cordobesa de signo socialista el gobierno necesitó que la CGT nacional la interviniera. Posteriormente, la identificación política de la FOC con el Partido Laborista, partido que al poco tiempo de creado perdió la aquiescencia de Perón, sumado a la competencia de una reestructurada CGT local bajo lineamientos oficialistas, contribuyeron a un rápido debilitamiento y desaparición de la FOC.

En agosto de 1945 parte del Comité Intersindical (gráficos, obreros de la construcción y pintores) más la Federación Local Obrera del Transporte Automotor, gastronómicos, molineros y papeleros participaron en un Congreso Obrero Intersindical,

\footnotetext{
${ }^{38}$ La Voz del Interior, 27 de noviembre de 1945, p. 11; 23 de febrero de 1948, p. 7; Los Principios, 23 de febrero de 1948, p. 3; Ferrero, op. cit., p. 106.

${ }^{39}$ La Voz del Interior, 11 de abril de 1944, p. 7; Los Principios, 20 de octubre de 1944, p. 2; 17 de enero de 1945, p. 8; Archivo de Gobierno de la Provincia de Córdoba, Serie Gobierno, 1945, tomo 19, fs. 4-7; Archivo General de la Nación, Ministerio del Interior. Comisión Ordenamiento de Archivos. Expedientes secretos, confidenciales y reservados, caja 41, expediente 999-R-1945, enero de 1945.

${ }^{40}$ La Voz del Interior, 13 de abril de 1945, p. 9.

${ }^{41}$ Tcach, Sabattinismo y peronismo. Partidos políticos en Córdoba 1943-1955, op. cit., 92-93.
} 
que contó con la adhesión de la Juventud Radical y de la Liga de los Derechos del Hombre. Allí exigieron al gobierno el regreso a la normalidad constitucional mediante la intervención directa de la Corte Suprema y el llamado a elecciones sin candidato oficial. Igualmente exhortaron por la libertad de prensa, reunión y palabra, la absoluta independencia sindical libre de tutela, el levantamiento del estado de sitio, la libertad de los presos políticos y sociales y el retorno de los exiliados. En un clima de entusiasmo, vivaron a la democracia, la libertad y al PC y trataron la posibilidad de crear un organismo gremial provincial independiente de la CGT. ${ }^{42}$ Este espacio se concretó con la organización de la Unión Obrera Local (UOL), autoproclamada como la "entidad que agrupa a la mayoría de los gremios obreros de Córdoba". En octubre de 1945 esta central pidió hacer caso omiso a la convocatoria de huelga general de la CGT para el 18 de octubre, porque consideraba que se trataba de una maniobra de la Secretaría de Trabajo y Previsión (STyP). En Córdoba, los participantes en el paro de ese día, que ocasionaron destrozos, eran calificados por la UOL como elementos desclasados dirigidos por patotas. Además juzgaba que los problemas de la carestía de la vida, la baja de salarios, la falta de cumplimiento de las leyes, las trabas al comercio y a la industria y el cierre de los mercados externos eran consecuencia de "la política nefasta de la dictadura agonizante." Igualmente rechazaba el decreto de aguinaldo de fines de 1945 por demagógico, pues consideraba que tales incrementos serían trasladados por la patronal a los bienes y servicios que comercializaban, perjudicando a la población en general. ${ }^{43}$

Más arriba mencioné que en estos años también se crearon sindicatos paralelos, los casos más paradigmáticos son en los sectores maderero, del comercio, de la construcción y la metalurgia y entre los sastres y obreros del dulce o confiteros. Existen los ejemplos de organizaciones preexistentes a nivel nacional que se fortalecieron bajo la protección de la STyP, como UOCRA (construcción) y UOM (metalurgia). Empero, en Córdoba sus referentes locales provinieron de sectores pro peronistas y contaron con una autonomía muy limitada debido a sus tempranas intervenciones. A pesar de que a nivel nacional ya se había fundado la UOCRA en 1943, como resultado de escisiones internas, en la ciudad mediterránea la promoción de un sindicato de la construcción paralelo fue más trabajosa, probablemente porque la hegemonía comunista en esta actividad y afines era casi completa. Una manera de debilitar al Sindicato de Obreros de la Construcción (SOC) fue mediante una nueva detención de sus dirigentes Cruz Ramírez y Carlos Pérez en mayo de 1945. No obstante, este no menguó su enfrentamiento con el gobierno ni perdió dirigentes cooptados por el peronismo, rasgo que fue común entre los sindicalistas comunistas de Córdoba. Aquí, recién a fines de 1945 se podrá constituir la Unión Obrera de la Construcción (UOC), un sindicato oficialista adherido a la CGT local y apoyado por el gobierno, que, sin embargo, no tardó en ser intervenido por la central trabajadora en agosto de $1946 .{ }^{44}$

\footnotetext{
${ }^{42}$ La Voz del Interior, 1, 5 y 18 de agosto de 1945, p. 12, 9 y 7, respectivamente.

${ }^{43}$ Los Principios, 6 y 10 de enero de 1946, p. 4 y 3 respectivamente; La Voz del Interior, 5, 6, 8, 10, 11 y 15 de enero de 1946.

${ }^{44}$ La Voz del Interior, 27 de noviembre de 1945, p. 11; 21 de agosto de 1946, p. 5 y 10 de octubre de 1946, p. 9; Archivo de Gobierno de la Provincia de Córdoba, Serie Gobierno, 1946, tomo 27, fs. 2 y 3. Otros dirigentes sindicales comunistas que hacia 1945 continuaban detenidos eran Isacc Blatt (empleado de comercio), Carlos Céliz (tipógrafo), Sajario Feldman (empleado), Alejandro Guignes y Hugo García (panaderos) y Antonio Juan
} 
Por su parte, los metalúrgicos conformaban el Comité Intersindical de mayoría comunista, al que se le opuso un sindicato propiciado por el Círculo Católico de Obreros que en noviembre de 1944 fue reconocido por la DRStyP. Sin embargo, este será intervenido por la UOM nacional a mediados de $1947 .^{45}$

Párrafo aparte merece la situación de los ferroviarios y de los empleados de comercio. Estas filiales sindicales se encontraban enfrentadas con sus organizaciones nacionales y a la vez afrontaban conflictos en su interior. En el caso de la Unión Ferroviaria, entre agosto y septiembre de 1945 la seccional Córdoba se posicionó contraria a realizar cualquier homenaje al gobierno y al accionar de la entidad a nivel nacional, aunque en la misma fecha algunos grupos de ese gremio visitaron al interventor para demostrar su adhesión a la política social del gobierno nacional. ${ }^{46}$ Respecto de los mercantiles, la orientación de la comisión directiva era socialista, pero el acercamiento del dirigente mercantil nacional Ángel Borlenghi al gobierno militar a través de la figura de Perón motivó el rechazo del CEC. Concretamente, denunciaron la posición colaboracionista del dirigente sindical nacional con "la dictadura"47 y su pretensión de negociar electoralmente. La importancia numérica del sector laboral representado y la oposición del CEC al gobierno militar y a la Confederación de Empleados de Comercio motivaron que la última promoviera otra entidad para disputarle afiliados: la Asociación Gremial de Empleados de Comercio (AGEC), fundada en noviembre de 1945 . $^{48}$

En cuanto a los sastres, asociaciones católicas como la Acción Católica y el Círculo de Obreros habían fundado respectivamente en 1938 y 1944 un sindicato de costureras católicas y una asociación católica de sastres, cortadores y anexos, para competir con el sindicato de sastres y costureras liderado por el socialista Miguel Ávila. En 1945 el promovido por el Círculo se incorporó a la FOC y abandonó la denominación "católica". 49 El Sindicato de Obreros Madereros fue otro de los gremios paralelos, surgido en 1948 bajo la dirección de Ambrosio Sánchez. ${ }^{50}$ Enfrentó exitosamente al sindicato Obrero de la Madera, de tendencia izquierdista, y ha logrado sobrevivir hasta la actualidad bajo el nombre de Unión Obreros y Empleados de la Industria de la Madera.

Podemos decir entonces que, a diferencia de Buenos Aires, en Córdoba las dirigencias sindicales con una trayectoria vinculada al comunismo y al socialismo como la federación de la construcción, el CEC y los sindicatos de gráficos, metalúrgicos, pintores, entre otros, no fueron cooptados por el peronismo. Puntualmente, gremialistas como los socialistas Miguel Ávila (sastre), Bruno Herrera (ferroviario), Mariano García (mercantil) y

Marelli (ferroviario). Archivo General de la Nación, Ministerio del Interior. Comisión Ordenamiento de Archivos. Expedientes secretos, confidenciales y reservados, caja 14, expediente 522-R-1945, mayo de 1945.

${ }^{45}$ Los Principios, 15 de noviembre de 1944, p. 5, La Voz del Interior, 21 de julio de 1947, p. 7.

${ }^{46}$ Los Principios, 27 de agosto de 1945, p. 1 , 18 de septiembre de 1945, p. 3 y 3 de octubre de 1945, p. 1; Córdoba, 12 de septiembre de 1945, p. 7.

${ }^{47}$ En julio de 1945 Borlenghi había encabezado un acto de la CGT en defensa del programa social del gobierno como reacción a la fuerte campaña opositora. Ver extractos de su discurso en Doyon, op. cit., 145147.

${ }^{48}$ Córdoba, 20 de septiembre de 1945, p. 3; Los Principios, 22 de agosto de 1945, p. 3; La Voz del Interior, 6 de agosto de 1945, p. 9; 27 de noviembre de 1945, p. 11.

${ }^{49}$ Blanco, "Religión, sindicalismo...", op. cit.

${ }^{50}$ Ferrero, op. cit., 113. 
Lucio Luna (maderero) fueron contrarios a Perón. Lo mismo puede decirse de los comunistas Miguel Contreras, Cruz Ramírez y Carlos Pérez (construcción), Carlos Céliz (gráfico), Hugo García y Alejandro Guignes (panaderos), Manuel Pelliza (tranviario) e Isaac Blatt (comercio). En cuanto a los últimos, sin embargo, si comparamos sus trayectorias sindicales y políticas, concluimos que pudieron expresar mejor su oposición como miembros y candidatos del PC que como gremialistas, puesto que desde 1943 sufrieron la cárcel y desde 1945 sus gremios fueron invalidados como organizaciones de los obreros, aunque algunos pudieron mantenerse al frente de sindicatos autónomos del peronismo hasta $1948 .{ }^{51}$ Otros directamente desaparecerán de la escena política y sindical como el comunista Ovidio Navarro (fideero).

En síntesis, lo anteriormente desarrollado evidencia la fortaleza de la izquierda en sindicatos númericamente gravitantes (gráficos, empleados de comercio, trabajadores de la construcción) y la heterogeneidad ideológica del movimiento obrero cordobés, donde convivieron varias centrales y sindicatos de diverso origen: en 1944 el Comité Intersindical y la CGT de signo izquierdista; sindicatos patrocinados por el Círculo de Obreros favorable al gobierno militar y desde mediados del año siguiente la UOL opuesta a la FOC y a la CGT pro peronistas.

\section{Las dirigencias sindicales comunistas cordobesas ante el triunfo de Perón y las directivas centrales del PC: resistencia y final integración}

El XI Congreso Nacional del Partido Comunista, celebrado entre el 14 y el 18 de agosto de 1946, es considerado por la historiografía del PC mencionada en la introducción como un punto de inflexión en las relaciones entre el comunismo y el peronismo. Luego del triunfo presidencial de Perón, el partido efectuó una autocrítica por haber subestimado la

\footnotetext{
${ }^{51}$ La Voz del Interior, 4 de junio de 1940, p. 9. Ver los candidatos del PC y del PS que apoyan la fórmula Tamborini-Mosca en La Voz del Interior, 7 y 21 de enero de 1946, p. 7; 27 y 28 de abril de 1947, p. 7 y 9 respectivamente; Los Principios, 24 de febrero de 1946, pp. 4 y 7; Córdoba, 8 de noviembre de 1951, p. 7. Entre los postulantes de ambos partidos para diputados nacionales en 1948 aparecen Miguel Ávila (PS) y Hugo García y Miguel Contreras (PC). La Voz del Interior, 7 de marzo de 1948, p. 11. Entre los candidatos del PS y del PC en las elecciones de noviembre de 1951 figuran Lucio Luna y Miguel Ávila (PS) y Juan e Isacc Blatt, Miguel Contreras, Carlos Pérez, Jesús Manzanelli y Manuel Pelliza (PC), Córdoba, 10 de noviembre de 1951, p. 3.

Dentro de las estructuras partidarias del comunismo cordobés, de los mencionados quienes cuentan con una trayectoria más visible a nivel dirigencial son Hugo García (presidente y vocal entre 1942 y 1950); Cruz Ramírez (miembro de la comisión directiva en 1943 y 1945-1947 y candidato a diputado provincial en 1951); Isacc Blatt (candidato a senador provincial en 1946 y a diputado provincial en 1951; vocal entre 1947 y 1948); Carlos Pérez (vocal en 1939 y 1948 y candidato a diputado provincial en 1946 y 1951); y Miguel Contreras (miembro de la comisión directiva por lo menos en 1947, 1948, 1950 y 1954; candidato a cargos electivos ejecutivos y legislativos en 1946, 1948, 1951 y 1954). Los Principios, 24 de febrero de 1946, pp. 4 y 7; La Voz del Interior, 7 de enero de 1946, p. 7; 14 de enero de 1947, p. 1; 26 de enero de 1948, p. 9; 16 de octubre de 1950, p. 9; Córdoba, 10 de noviembre de 1951, p. 3; Achával Becú, Las culturas políticas..., op. cit., 128.

Pueden consultarse las biografías políticas de Miguel Contreras y los hermanos Manzanelli en Tarcus, Horacio (dir.), Diccionario biográfico de la izquierda argentina, Emecé, Buenos Aires, 2007, 145-147 y $385-$ 388. Cf. Di Tella, op. cit.,132.
} 
influencia peronista en vastos sectores de la sociedad y lo reinterpretó como un movimiento social y políticamente heterogéneo, compuesto tanto por fuerzas progresistas como reaccionarias, que se estaban reagrupando en un partido de gobierno jerarquizado en el que el sector obrero tenía todas las de perder. Ante este diagnóstico, el PC se propuso como estrategia -de acuerdo con la política frentepopulista adoptada desde 1935-, formar un nuevo frente progresista antioligárquico y antiimperialista, sin ningún tipo de distinciones políticas, culturales o religiosas. En referencia al gobierno, la táctica fue la de la crítica constructiva, apoyando lo positivo y denunciando las medidas que consideraban negativas. En cuanto a la clase obrera, las resoluciones del Congreso indicaban que los militantes comunistas debían autodisolver los sindicatos hegemonizados por ellos e integrarse a los peronistas y a la CGT, luchando desde el interior del peronismo para guiar el triunfo de las fuerzas progresistas y democráticas. ${ }^{52}$

En lo que respecta al fuerte sindicato de la construcción, días después del XI Congreso, el SOC a nivel nacional solicitó su propia intervención a la CGT. Sin embargo, los comportamientos de las dirigencias sindicales comunistas cordobesas no se condecían con las directivas centrales del partido en lo que refiere a la disolución de sus organizaciones e integración en la estructura sindical peronista. Así, entre octubre y noviembre de 1946 el sindicato de la construcción de la Capital, liderado por el vocal del PC Cruz Ramírez, llevó a cabo una extensa huelga motivada por el rechazo patronal a la exigencia obrera de aumento salarial y mejora en las condiciones de trabajo. El conflicto logró la solidaridad de otros actores sindicales y políticos, como la Unión Trabajadores del Transporte Automotor (UTTA), la Federación Universitaria de Córdoba y la Asociación de Maestros. El apoyo de la UCR y de las Mujeres radicales seguramente se debió a la influencia de Horacio Villarreal, cercano a ese partido y en ese momento prosecretario del comité de huelga. ${ }^{53}$

En su análisis de las modalidades que adoptaron las huelgas entre 1946 y 1948, Doyon concluye que en términos generales los conflictos fueron promovidos y dirigidos por los sindicatos legalmente reconocidos, con el objeto de mejorar las condiciones de los trabajadores, es decir para ampliar derechos pero no crear nuevos. El resultado fue casi siempre exitoso, en gran parte debido a la inclinación pro obrera del gobierno que condicionó la actitud patronal. Sin embargo, para la ciudad de Córdoba la autora atribuye erróneamente a la UOC la dirección del movimiento huelguístico recién mencionado. Ella y otros autores, como del Campo, parten del supuesto de que los sindicatos antiperonistas -incluidos los comunistas- después de las elecciones presidenciales de 1946 se disolvieron formalmente o desaparecieron. ${ }^{54}$ Incluso Doyon adelanta esta fecha y afirma que "Los trabajadores de este sector [construcción] constituyen el único grupo en el que un poderoso sindicato comunista fue arrasado por el gobierno militar entre 1943 y 1945 " 55 Si bien la FONC fue disuelta en 1946, esto no fue óbice para la continuación de las actividades por

\footnotetext{
${ }^{52}$ Staltari, op. cit., 16-19; Schiavi, "Los sindicatos comunistas entre el 17 de octubre y su disolución...”, op. cit.

${ }^{53}$ La Voz del Interior, 21 de agosto de 1946, p. 5; 16, 17 y 19 de octubre de 1946, p. 9, 10 y 7, respectivamente; 2 de noviembre de 1946, p. 7; Los Principios, 16 de octubre de 1946, p. 9.

${ }^{54}$ Doyon, op. cit., 276 y 278; Del Campo, op. cit., 187.

${ }^{55}$ Doyon, op. cit., 270.
} 
parte de sus sindicatos adheridos, como ocurrió en la ciudad de Córdoba, donde los elementos comunistas se hicieron sentir por lo menos hasta fines de $1947 .^{56}$

El SOC formaba parte de los autodenominados sindicatos autónomos, junto con los del dulce y de la madera, los gastronómicos, canillitas, Unión General de Mozos, cocineros, tabacaleros, barman y cafeteros, mucamas, Unión Obrera de Bodegas y Destilerías y los centros de empleados de comercio, de farmacias y droguerías y de viajantes de comercio. Durante el mitin en conmemoración del $1^{\circ}$ de mayo de 1947 , separado del organizado por la delegación regional de la CGT, estos sindicatos se pronunciaron por "una real independencia y democracia sindical, por el fiel cumplimiento y ampliación de la legislación obrera y por la reducción del costo de la vida" y denunciaron a la CGT por extorsiva y contraria a los intereses de los trabajadores. ${ }^{57}$ A pesar de su pasado anarquista, socialista y comunista, no podemos afirmar que hacia ese año la orientación de esas dirigencias fueran izquierdistas; sin embargo, lo anterior brinda elementos para pensar en un panorama sindical que todavía continúa segmentado política e ideológicamente, con una llamativa resistencia a la CGT, en sentido contrario a la exhortación sindical asimilacionista de la cúpula comunista. La solidaridad gremial también es un punto a destacar, no solo en el conflicto de los obreros de la construcción. En efecto, en los sectores del transporte y servicios cabe señalar la huelga de la UTTA, destacada tanto por su duración (entre septiembre y octubre de 1947), por las causas como por los actores intervinientes. El desacuerdo fue producido por cuestiones gremiales: la Comisión Administradora del Transporte Automotor, de origen estatal, había desconocido el convenio de trabajo y a la misma UTTA, ordenando suspensiones y cesantías injustificadas, entre ellas las de experimentados dirigentes como el radical Oscar Colla, el socialista Juan Siles y el comunista Zveton Georgieff. El sindicato a la vez denunció que se formó una organización rompehuelga peronista, el Sindicato Obrero del Transporte Automotor (SOTA), cuyos integrantes manejaban los coches. El conflicto contó con la participación de los sindicatos de la madera, de la construcción, peluqueros y peinadores, el Centro de Empleados de Comercio y la Federación Obrera Gráfica que conformaron un comité intersindical para propender -infructuosamente- a la unión de los obreros de UTTA y de SOTA. También se solidarizaron explícitamente con la huelga de UTTA la UCR, el Partido Comunista, el SOC y el CEC. El asunto terminó con más de doscientos obreros encarcelados y dirigentes detenidos y con el decreto de reconocimiento de SOTA -que afirmaba agrupar a más de quinientos trabajadores- en reemplazo de UTTA -con más de novecientos- para representar al gremio. ${ }^{58}$

A diferencia de la hermandad y coordinación mutua entre el comunista Sindicato Obrero de la Industria Metalúrgica y la UOM luego de las elecciones presidenciales de

\footnotetext{
${ }^{56}$ Celia Durruty, Clase obrera y peronismo, Córdoba, Ediciones Pasado y Presente, 1969, 65; Ferrero, op. cit., 116; Los Principios, 24 de enero de 1948, p. 3.

${ }^{57}$ La Voz del Interior, 28 y 30 de abril y 2 de mayo de 1947, p. 9.

58 Jessica Blanco, "Las estrategias de hegemonía sindical peronista ante la oposición de la vieja guardia sindical cordobesa", ponencia presentada en Tercer Congreso de Estudios sobre el Peronismo(1943-2012), San Salvador de Jujuy, CD-ROM, 18 a 20 de octubre de 2012. Cabe aclarar que SOTA era un sindicato preexistente a 1943.
} 
1946 estudiado por Marcos Schiavi, ${ }^{59}$ en Córdoba SOC y UOC coexistieron en competencia y con críticas mutuas por lo menos hasta fines de 1947. Sin embargo, cabe reconocer que el primero subsistía diezmado: a mediados de ese año declaraba poco más de 3.000 asociados entre las distintas ramas. En ocasión del Congreso Obrero convocado por la CGT en julio de 1947, al que no fue invitado, el SOC se pronunció respecto del Primer Plan Quinquenal y contrariamente a la actitud favorable de la CGT, coincidió con la finalidad del proyecto de industrialización del país y el incremento de la productividad, pero a través de la tecnificación y no solo por el aumento del trabajo intensivo. ${ }^{60}$

En 1947 la CGT local ya se había impuesto como la única central sindical y agrupaba, entre otros, a los municipales, telefónicos, tranviarios y los empleados de comercio de la oficialista AGEC. ${ }^{61}$ Con todo, el hecho de que los sindicatos contaran con dirigencias afines al peronismo no significaba obsecuencia ante todas sus medidas. Su intervención por parte de la CGT nacional, en enero de 1948, la convirtió en una entidad completamente dependiente y ejecutora de las directivas nacionales.

Durante esos meses de intervención por parte de la CGT nacional, la central local logró la integración de los sindicatos que aún no se habían adherido a través de la neutralización total de los resabios izquierdistas presentes en ellos, como en la Unión General de Mozos, gastronómicos, ladrilleros, pintores, panaderos y gráficos.

En el caso de los panaderos, en 1947 se consigna la última mención de la Sociedad de Resistencia Obreros Panaderos, con el comunista Alejandro Guignes como miembro de la Junta Paritaria, aunque dos años después aparece una Sociedad de Obreros Panaderos y Ayuda Mutua. El proceso de extinción de una y la fundación de la otra hasta ahora es desconocido, aunque a nivel dirigencial la nueva situación solo fue aceptada por Zenón Guevara, miembro de la Junta Paritaria de la Sociedad de Resistencia que en la nueva sociedad ascendió al cargo de secretario general. El resto de la comisión directiva del sindicato más antiguo desapareció de la escena sindical y su sede pasó a ser ocupada por su reemplazante. $^{62}$

Entre los gráficos, un grupo fundó la Unión Gráfica Cordobesa que contó entre su dirigencia a Jesús Castro, en 1945 secretario adjunto de la Federación Gráfica de Córdoba, organización que hacia noviembre de 1948 continuaba presidida por el histórico secretario general comunista Carlos Céliz, que resistía presiones de renuncia. Algo similar ocurrió en el sector de la construcción con el dirigente Juan Casiano Coria, quien había renunciado como vocal del SOC en diciembre de 1947 por no estar de acuerdo con la orientación de la Comisión Administrativa y en mayo del año siguiente figuraba como secretario general de la UOC, el único que detentaba la personería gremial. ${ }^{63}$ Posteriormente las referencias al

\footnotetext{
${ }^{59}$ Schiavi, "Los sindicatos comunistas entre el 17 de octubre y su disolución...", op. cit, 18.

${ }^{60}$ La Voz del Interior, 10 de octubre de 1946, p. 9 y 19 de julio de 1947, p. 9.

${ }^{61}$ La Voz del Interior, 20 de julio de 1947, p. 10.

${ }^{62}$ La Voz del Interior, 30 de abril de 1949, p. 9; Los Principios, 28 de abril de 1950, p. 5. Cf. Comisiones directivas de ambas entidades en La Voz del Interior, 13 de enero de 1947, p. 5 y 12 de diciembre de 1952, p. 5 .

${ }^{63}$ La Voz del Interior, 22 y 24 de febrero de 1949, p. 7; 4 de diciembre de 1947, p. 11; 9 de agosto de 1948, p. 11 y 30 de noviembre de 1948, p. 7; Los Principios, 6 de mayo de 1948, p. 7 y 28 de abril de 1950, p. 5. Luego del golpe militar de 1955 Céliz integró una comisión asesora de la intervención al gremio a nivel
} 
SOC desaparecen en las fuentes, lo que junto al pase anterior nos están hablando de una probable autodisolución e integración, no sin conflictos, a la UOC:

[individuos que]...no admitieron el mandato mayoritario que reclamaba apoyo leal a la campaña de renovación sindical que en el país se opera y ahora que se ven desplazados se dedican a insultar a funcionarios ejemplares en actuación, a tildar de divisionistas a quienes no los secundan en sus planes y formar comisiones destinadas a recorrer las obras intimando a los compañeros para que abandonen el trabajo a los efectos de poder demostrar y justificar su permanencia en posiciones directivas que hace mucho tiempo debían haber abandonado en bien de la clase trabajadora. ${ }^{64}$

Al parecer, en mayo de 1948 Ramírez -y seguramente otros miembros del SOC- se afilió a la UOC, decisión que debe haber incidido en la definitiva unificación gremial del sector. $^{65}$

En el transcurso de 1948 en Córdoba, los casos de desaparición, autodisolución y/o integración en los sindicatos oficialistas (Sociedad de Resistencia Obreros Panaderos, Federación Gráfica de Córdoba y SOC) y la anulación de dirigentes gremiales comunistas como el gráfico Carlos Céliz, el panadero Alejandro Guignes o el albañil Cruz Ramírez tal vez puedan explicarse más por un condicionante local del campo sindical, como fue la presión ejercida por la intervención de la CGT cordobesa, que por acatamientos tardíos a las directivas del PC.

\section{Conclusiones}

En la década de 1990, las interpretaciones autodenominadas extra-céntricas sobre los orígenes del peronismo propusieron explicar su formación en el interior del país haciendo hincapié en el aporte ideológico y en cuadros de los sectores políticos y sociales tradicionales de esas comunidades. Con el extra-centrismo se superó una ausencia, pero esta nueva presencia desvió la mirada y llevó a invisibilizar o sub-problematizar a priori la influencia política del movimiento obrero organizado, que se creyó casi inexistente por asociarlo irremediablemente a un proceso de industrialización significativo.

En Córdoba, los gobiernos sabattinistas fueron centrales en el fomento de las organizaciones obreras, entre ellas las sindicales, lo cual se evidencia en su duplicación durante el lustro 1936-1941. Las nuevas entidades se sumaron a las ya existentes de sastres, madereros, ferroviarios, gráficos, empleados de comercio y de la construcción, lideradas

nacional, y desde 1957 formó parte del Comité Central de la Federación Argentina de Trabajadores de la Imprenta.

http://www.fatida.com/index.php?option=com_content\&view=article \&id=48\&Itemid=57\&limitstart=4 .

${ }^{64}$ Los Principios, 24 de enero de 1948, p. 3.

${ }^{65}$ Los Principios, 3 de junio de 1948, p. 3. En 1949, Cruz Ramírez reclamaba la reincorporación a la UOC y la vigencia de la ficha de afiliación, que le había sido cancelada en mayo del año anterior. La Voz del Interior, 8 de marzo de 1949. 
por socialistas y comunistas y poseedoras de un caudal de aprendizaje acumulado en años de luchas y negociaciones. La influencia de ambas tendencias ideológicas en los distintos sectores productivos y de servicios replicaba a grandes rasgos la representación a nivel nacional. Igualmente, en Córdoba cabe recalcar la mayor visibilidad y peso relativo de los comunistas, probablemente porque representaban sectores claves de la estructura productiva cordobesa, como la alimentación y la construcción, porque contaron con centrales propias hasta 1945 (la UOP, la FOP, el Comité Intersindical y la UOL) y por la ausencia como competencia orgánica de una corriente de línea sindicalista.

La aparición del peronismo en la escena política y social constituyó un punto de inflexión en la historia argentina desde mediados del siglo XX, definiendo opositores, simpatizantes y partidarios, y entre los trabajadores dio origen a la formación de variadas construcciones de identidad, entre las que sobresale la peronista. Puntualmente, las dirigencias sindicales de Córdoba experimentaron un proceso de transformación en dos direcciones. Por un lado, surgieron nuevos dirigentes y algunos antiguos se adecuaron y fueron cooptados por el nuevo liderazgo; por otro, se produjo una resistencia de la mayoría de los comunistas y socialistas.

Para entender el fenómeno peronista en Córdoba resulta de poca utilidad aplicar la lógica interpretativa de su surgimiento en Buenos Aires, que centra la mirada en el sector obrero y particularmente en las dirigencias sindicales de antigua data. En cambio, en el ámbito gremial de la ciudad mediterránea quienes apoyaron a Perón fueron dirigentes con poca experiencia y nuevos sindicatos promovidos por la FOC y la DRSTyP. Ahora bien, acabo de demostrar que, al igual que en Capital Federal, existía una "vieja guardia sindical" pese a las diferencias del desarrollo industrial entre ambas ciudades. Esta estaba compuesta mayoritariamente por dirigentes comunistas y socialistas y su oposición a la política sindical del gobierno militar fue combatida en términos individuales a través del hostigamiento policial y la prisión de los principales referentes, y a nivel colectivo mediante la fundación de sindicatos paralelos con personería gremial, la creación de nuevos sindicatos en áreas todavía no agremiadas y la atracción de sindicatos preexistentes que se encontraban bajo la promoción del Círculo Católico de Obreros. Este arco sindical, liderado mayoritariamente por dirigentes con nula o escasa experiencia en ese ámbito, constituyó la base de sustentación gremial del peronismo local.

De todos modos, dicho proceso de hegemonía peronista en el ámbito sindical necesitó más de tres años y recién logró consagrarse exitosamente en 1948 por la claudicación final de dirigentes sindicales comunistas -que habían desafiado las directivas de integración ordenada por el PC central al sindicalismo peronista y a la CGT-, ante la eficaz presión de una CGT recientemente intervenida.

En este sentido, los estudios sobre el PC argentino durante el primer peronismo ubican a los meses posteriores al primer triunfo presidencial de Perón como un tiempo de autodisolución e integración de los sindicatos comunistas en los peronistas. Esta "tesis de la asimilación" no da cuenta en términos satisfactorios de los casos de dirigentes y organizaciones sindicales cuyas prácticas evidenciaron una autonomía relativa de las directivas del partido. Así, en Córdoba no solo encontramos un peronismo profundamente condicionado por las situaciones locales, sino también líderes comunistas que, por lo menos a nivel sindical, parecen no seguir ciega y acríticamente las directivas nacionales del 
partido. Hasta 1948 aparecen casos de dirigentes obreros y sindicatos integrados por comunistas o bajo su conducción, como los panaderos, los gráficos y los obreros de la construcción que, a pesar de las disposiciones del XI Congreso, se opusieron a la CGT y a autodisolver sus organizaciones para sumarse a los sindicatos peronistas.

Ahora bien, cabría preguntarse cómo fueron las reacciones al interior del partido por estos comportamientos contrarios a las directivas centrales del partido, en términos de discusiones, escisiones, disputas internas, desplazamientos, etc. Asimismo, luego de 1948, cómo se habrá operativizado la integración comunista, sobre todo a nivel de los mecanismos planteados para influenciar los sindicatos peronistas desde adentro, pero también los conflictos identitarios que la orden asimilacionista debe haber ocasionado en algunos militantes o dirigentes. Estos interrogantes quedan pendientes de resolver; sin embargo, considero que el artículo invita a revisar otros casos regionales, en lo que se refiere a las diferentes estrategias implementadas por los peronismos locales ante cada coyuntura sindical provincial, ${ }^{66}$ y a estudiar con mayor profundidad un tema prácticamente ignorado, tanto desde los estudios sobre movimiento obrero y peronismo como de quienes focalizan su interés en la historia del PC argentino: las prácticas concretas de los dirigentes y militantes comunistas en los sindicatos durante la conformación del peronismo y durante las dos primeras presidencias de Perón. Este trabajo se propuso ser un avance en ambos sentidos.

Recibido: 15 enero $2016 \quad$ Aprobado: 2 abril 2016

\section{Referencias bibliográficas}

\section{Impresas}

Inés Achával Becú, Las culturas políticas y el origen del peronismo en Córdoba (19431947), Tesis de Licenciatura en Historia, Córdoba, Universidad Nacional de Córdoba, 2010, inédito.

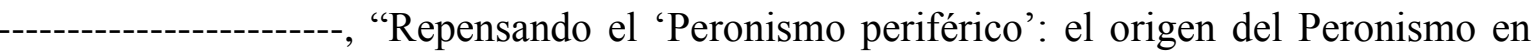
Córdoba 1943-1946", ponencia presentada en el Segundo Congreso de Estudios sobre el Peronismo 1943-1976, UNTREF, 4 al 6 de noviembre de 2010, disponible en http://redesperonismo.com.ar/archivos/CD2/Achaval.pdf

Daniel Darío Amuchástegui, Gobierno y oposición ante la cuestión social en Córdoba, 1932-1936, Tesis de Licenciatura en Historia, Córdoba, 1986, inédito.

\footnotetext{
${ }^{66}$ Un primer avance en este sentido en Jessica Blanco, "Tras la huella católica en los sindicatos. Una aproximación comparativa a los casos de Mendoza y Córdoba (1943-1945)", ponencia presentada en $I V$ Jornadas Interdisciplinarias de Investigaciones Regionales "Enfoques para la historia”, Mendoza, 7 a 9 de octubre de 2015, inédito.
} 
Jessica Blanco, "Las estrategias de hegemonía sindical peronista ante la oposición de la vieja guardia sindical cordobesa", ponencia presentada en Tercer Congreso de Estudios sobre el Peronismo(1943-2012), San Salvador de Jujuy, CD-ROM, 18 a 20 de octubre de 2012.

--------------, Mundo sindical, esfera política y catolicismo en Córdoba, 1940-1955. La Juventud Obrera Católica durante el peronismo, Tesis doctoral en Historia, Córdoba, Universidad Nacional de Córdoba, 2012, inédita.

-----, "Religión, sindicalismo y política en los años '40: una revisión sobre la participación católica en los sindicatos durante los años formativos del peronismo", Gardenia Vidal y Jessica Blanco (comps.), Catolicismo y política en Córdoba, siglos XIX y XX, Córdoba, Ferreyra Editor, 2010, 133-163.

--------, "Tras la huella católica en los sindicatos. Una aproximación comparativa a los casos de Mendoza y Córdoba (1943-1945)", ponencia presentada en IV Jornadas Interdisciplinarias de Investigaciones Regionales "Enfoques para la historia", Mendoza, 7 al 9 de octubre de 2015, inédita.

James Brennan, El Cordobazo. Las guerras obreras en Córdoba, 1955-1976, Buenos Aires, Sudamericana, 1994.

Hernán Camarero, A la conquista de la clase obrera. Los comunistas y el mundo del trabajo en la Argentina 1920-1935, Buenos Aires, Siglo XXI, 2007.

-------------------, “Antiguas controversias, nuevos enfoques: Clase obrera, sindicalismo y comunismo en la Argentina durante la primera mitad del siglo XX: Un estado de la cuestión," PolHis, 6:11, primer semestre de 2013, 129-146, disponible en http://historiapolitica.com/datos/boletin/PolHis11.pdf

Hugo del Campo, Sindicalismo y peronismo. Los comienzos de un vínculo perdurable, Buenos Aires, Clacso, 1983.

Torcuato Di Tella, Perón y los sindicatos. El inicio de una relación conflictiva, Buenos Aires, Ariel, 2003.

Diario Córdoba

Diario El País

Diario La Voz del Interior

Diario Los Principios

Louise Doyon, Perón y los trabajadores. Los orígenes del sindicalismo peronista 19431955, Buenos Aires, Siglo XXI, 2006[1978].

Celia Durruty, Clase obrera y peronismo, Córdoba, Ediciones Pasado y Presente, 1969.

María Fernández de Ullivarri, Trabajadores, sindicatos y política en Tucumán. 1930-1943, Tesis de Doctorado en Historia, Buenos Aires, Universidad de Buenos Aires, 2010, inédita.

Roberto Ferrero, Del mutualismo al Cordobazo. Breve historia del movimiento obrero en Córdoba, Córdoba, Ediciones del Cepen, 2009.

Gino Germani, Estructura social de la Argentina, Buenos Aires, Ediciones Solar, 1987 [1955].

--------------,Política y sociedad en una época de transición, Buenos Aires, Paidós, 1962.

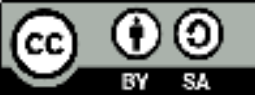


Andrés Gurbanov y Sebastián Rodríguez, "La compleja relación entre el Partido Comunista Argentino y el peronismo: (1943-1955)", ponencia presentada en Primer Congreso de Estudios sobre el Peronismo, Mar del Plata, noviembre de 2008, disponible en http://redesperonismo.com.ar/archivos/CD1/PP/gurbanov.pdf.

Aníbal Jáuregui, "El peronismo en los debates del Partido Comunista Argentino: 19451953”, A contracorriente, 9:3, Carolina del Norte, primavera 2012, 22-40.

Darío Macor y César Tcach (eds.), La invención del peronismo en el interior del país, Santa Fe, Universidad Nacional del Litoral, 2003.

Alicia Malatesta, "La actividad industrial en Córdoba (1930-1955)", Beatriz Moreyra y Beatriz Solveira, Estado, economía y sociedad en Córdoba, 1880-1950 I, Córdoba, CEH, 1997.

Alexia Massholder, "La relación entre comunistas y peronistas: algunas notas desde la historia", Cuadernos Marxistas, 5, Buenos Aires, noviembre de 2012, 35-40.

Mariana Mastrángelo, Rojos en la Córdoba obrera 1930-1943, Buenos Aires, Imago Mundi, 2011.

Hiroshi Matsushita, Movimiento obrero argentino 1930-1945, Buenos Aires, Hyspamérica, 1986 [1983].

Menotti, Paulo, "Relaciones entre el estado santafesino, el movimiento obrero y los comunistas antes del surgimiento del peronismo (1928-1943)", ponencia presentada en XIII Jornadas Interescuelas/Departamentos de Historia, Catamarca, Universidad Nacional de Catamarca, 10 al 13 de agosto de 2011.

Miguel Murmis y Juan Carlos Portantiero, Estudios sobre los orígenes del peronismo, Buenos Aires, Siglo XXI, 2004[1971].

María José Ortiz Bergia, "Construcción de políticas laborales en Córdoba, 1930-1943”, Población y sociedad, 16, Tucumán, 2009, 151-186.

María José Ortiz Bergia, La construcción del Estado Social en Córdoba entre 1930-1943: Actores y concepciones en un período de transición, Tesis de Licenciatura en Historia, Córdoba, 2007, inédito.

Ofelia Pianetto, "Sindicatos y política en Córdoba (1930-1943)", César Tcach (coord.), Córdoba bicentenaria. Claves de su historia contemporánea, CEA-UNC, Córdoba, 2010, 217-248.

Esteban Piliponsky, "De las calles a las urnas. Movimiento obrero, izquierdas y laboristas en Tucumán en la campaña electoral de 1946", Coordenadas. Revista de Historia Local y Regional, 1:2, Centro de Investigaciones Históricas de la Universidad Nacional de Río Cuarto, Río Cuarto, julio-diciembre de 2014, 118-145, disponible en http://ppct.caicyt.gov.ar/index.php/coordenadas/article/view/5241

------------------, “Sindicatos fuertes con poder de negociación débil? Análisis del sindicalismo tucumano previo al surgimiento del peronismo", A contracorriente. Una revista de historia social y literatura de América Latina, 10:1 Carolina del Norte, 2012, 310-333.

Marcos Schiavi, El poder sindical en la Argentina peronista (1946-1955), Buenos Aires, Imago Mundi, 2013.

---------, "Los sindicatos comunistas entre el 17 de octubre y su disolución. El caso textil y metalúrgico", ponencia presentada en las IX Jornadas de Sociología. 
Capitalismo del siglo XXI, crisis y reconfiguraciones. Luces y sombras en América Latina, Universidad de Buenos Aires, CD-ROM, Buenos Aires, 2011, disponible en http://historiapolitica.com/datos/biblioteca/pcmovo_schiavi.pdf;

Silvana Staltari, "El Partido Comunista frente al peronismo: estrategia y tácticas políticas, 1945-1955", Archivos de historia del movimiento obrero y la izquierda, 5, Buenos Aires, septiembre de 2014, 11-30.

Horacio Tarcus (dir.), Diccionario biográfico de la izquierda argentina, Buenos Aires, Emecé, 2007.

César Tcach, "Izquierda, movimiento obrero e intervencionismo estatal durante el gobierno de Amadeo Sabattini", ponencia presentada en las Segundas Jornadas Nacionales de Historia de Córdoba, CD-ROM, Córdoba, mayo de 2011.

-------------, "Ni cruces ni puños cerrados: la construcción de la hegemonía peronista en el movimiento obrero cordobés", Darío Macor y César Tcach (eds.), La invención del peronismo en el interior del país II, Santa Fe, Universidad Nacional del Litoral, 2013, 41-56.

, Sabattinismo y peronismo. Partidos políticos en Córdoba 1943-1955, Buenos Aires, Sudamericana, 1991.

Juan Carlos Torre, La vieja guardia sindical y Perón. Sobre los orígenes del peronismo, Buenos Aires, Sudamericana, 1990.

Oscar Videla y Paulo Menotti, "Una experiencia de la militancia comunista en los orígenes del peronismo. El Sindicato de Obreros de la Industria Metalúrgica (SOIM) de Rosario, A contracorriente, 11:2, Carolina del Norte, invierno 2014, 114 -144.

\section{Otras fuentes impresas (documentos públicos y privados)}

Archivo de Gobierno de la Provincia de Córdoba, Serie Gobierno.

Archivo General de la Nación, Ministerio del Interior. Comisión Ordenamiento de Archivos. Expedientes secretos, confidenciales y reservados.

Archivo Histórico Municipal, Documentos del Concejo Deliberante.

\section{Digitales}

http://www.cepal.org/publicaciones/xml/4/7394/lcg2140_tabpaises.pdf

http://www.fatida.com/index.php?option=com_content\&view=article \&id=48\&Itemid=57\& limitstart $=4$ 